2. To: (Receiving Organization)

Distribution

5. Proj/Prog./Dept./Div.:

Characterization Project

8. Originator Remarks:

The attached ETP is submitted for release.

3. From: (Originating Organization)

Characterization Engineering

6. Design Authority/Design Agent/Cog.

Engr::

CA Esvelt
4. Related EDT No:

N/A

7. Purchase Order No:

N/A

9. Equip./Component No.:

N/A

10. System/Bldg./Facility:

200 General

11. Receiver Remarks: 11A. Design Baseline Document? [] Yes [X] No

12. Major Assm. Dwg. No.:

N/A

13. Permit/Permit Application No.:

N/A

14. Required Response Date:

January 8, 1999

\begin{tabular}{|c|c|c|c|c|c|c|c|c|}
\hline 15. & & DATA & NSM & & (F) & (G) & (H) & (I) \\
\hline $\begin{array}{l}\text { (A) } \\
\text { Item } \\
\text { No. }\end{array}$ & (B) Document/Drawing No. & $\begin{array}{l}\text { (C) } \\
\text { Sheet } \\
\text { No. }\end{array}$ & $\begin{array}{l}\text { (D) } \\
\text { Rev. } \\
\text { No. }\end{array}$ & $\begin{array}{c}\text { (E) Title or Description of Data } \\
\text { Transmitted }\end{array}$ & $\begin{array}{l}\text { Approval } \\
\text { Desig- } \\
\text { nator }\end{array}$ & $\begin{array}{c}\text { Reason } \\
\text { for } \\
\text { Trans- } \\
\text { mittal }\end{array}$ & $\begin{array}{l}\text { Origi- } \\
\text { nator } \\
\text { Dispo- } \\
\text { sition }\end{array}$ & $\begin{array}{c}\text { Receiv- } \\
\text { er } \\
\text { Dispo- } \\
\text { sition }\end{array}$ \\
\hline 1 & HNF $=3640$ & & 0 & $\begin{array}{l}\text { ENGINEERING TASK PLAN FOR } \\
\text { PURGED LIGHT SYSTEM }\end{array}$ & $\mathrm{SQ}$ & 2 & 1 & \\
\hline & & & & & & & & \\
\hline & & & & & & & & \\
\hline & & & & & & & & \\
\hline
\end{tabular}

\begin{tabular}{|c|c|c|c|c|}
\hline & \multirow{2}{*}{\multicolumn{2}{|c|}{ Reason for Transmittal (G) }} & \multirow{2}{*}{\multicolumn{2}{|c|}{ Disposition (H) \& (I) }} \\
\hline & & & & \\
\hline $\begin{array}{l}\text { E, S, Q, D or N/A } \\
\text { (see WHC-CM-3-5, } \\
\text { Sec.12.7) }\end{array}$ & $\begin{array}{l}\text { 1. Approval } \\
\text { 2. Release } \\
\text { 3. Information }\end{array}$ & $\begin{array}{l}\text { 4. Review } \\
\text { 5. Post-Review } \\
\text { 6. Dist. (Receipt Acknow. Required) }\end{array}$ & $\begin{array}{l}\text { 1. Approved } \\
\text { 2. Approved w/comment } \\
\text { 3. Disapproved w/comment }\end{array}$ & $\begin{array}{l}\text { 4. Reviewed no/comment } \\
\text { 5. Reviewed w/comment } \\
\text { 6. Receipt acknowledged }\end{array}$ \\
\hline
\end{tabular}

17. SIGNATURE/DISTRIBUTION

(See Approval Designator for required signatures)

\begin{tabular}{|c|c|c|}
\hline $\begin{array}{l}\text { (G) } \\
\text { Rea- } \\
\text { son }\end{array}$ & $\begin{array}{c}\text { (H) } \\
\text { Disp. }\end{array}$ & (L) Date (M) MSIN \\
\hline 1 & 7 & Whacbl/19/9o 57-12 \\
\hline & & Design Agent $\mathrm{N} / \mathrm{A}$ \\
\hline 1 & 1 & Cog.Eng. CA Esvel \\
\hline 1 & 1 & Cog. Mgr. JS schofiel 2 pr \\
\hline 1 & 1 & 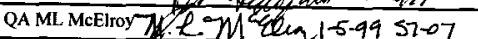 \\
\hline 1 & 1 & Safety JA Ranschau $9 \notin 41$ \\
\hline & & Env, N/A \\
\hline
\end{tabular}

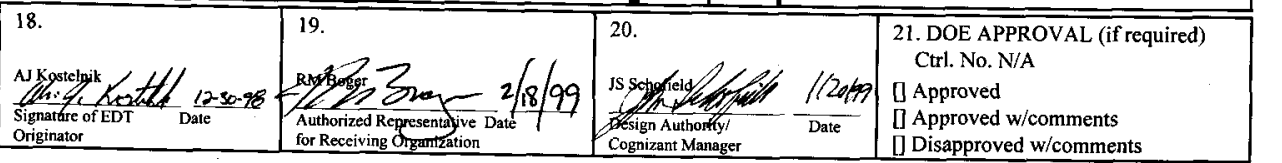




\title{
ENGINEERING TASK PLAN FOR PURGED LIGHT SYSTEM
}

\section{R. M. Boger}

Prepared by Lockheed Martin Hanford Corporation

Richland, WA 99352

U.S. Department of Energy Contract DE-AC06-96RL13200

\author{
EDT/ECN: 622150 \\ Org Code: 74900 \\ B\&R Code: EW3120074 \\ UC: 2070 \\ Charge Code: $102258 \mathrm{EI} 00$ \\ Total Pages: 13
}

Key Words:

video, closed circuit television, tank farm, characterization project

\begin{abstract}
:
This ETP defines the tasks and deliverables required to support the procurement of a new light system. The light is necessary to enhance the capabilities of the closed circuit video system used inside the Hanford waste tanks.
\end{abstract}

TRADEMARK DISCLAIMER. Reference herein to any specific commercial product, process, or service by trade name, trademark, manufacturer, or otherwise, does not necessarily constitute or imply its endorsement, recommendation, or favoring by the United States Government or any agency thereof or its contractors or subcontractors.

Printed in the United States of America. To obtain copies of this document, contact: Document Control Services, P.O. Box 950, Mailstop H6-08. Richland WA 99352, Phone (509) 372-2420; Fax (509) 376-4989.

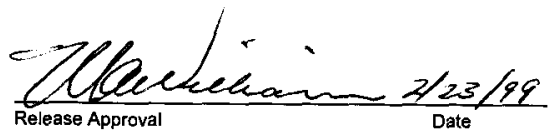

Approved For Public Release 


\title{
ENGINEERING TASK PLAN FOR PURGED LIGHT SYSTEM
}

\author{
Prepared by \\ A.J. Kostelnik \\ COGEMA Engineering Corporation \\ Richland, Washington \\ for \\ Characterization Engineering \\ Tank Waste Remediation System \\ Lockheed Martin Hanford Corporation \\ Richland, Washington \\ January 1999
}


$\begin{array}{lll}1.0 \text { INTRODUCTION } & 4\end{array}$

2.0 SCOPE 4

3.0 DESCRIPTION 4

3.1 Physical Description 4

3.2 Engineering Tasks 4

3.2.1 Design Requirements 4

3.2.2 Procurement Specifications 4

3.2.3 Design 5

3.2.4 Operating and Maintenance Procedures 5

3.2.5 Spare Parts 5

3.3 Design Verification $\quad 5$

3.4 Procurement / Fabrication Tasks

3.5 Installation Tasks $\quad 5$

3.6 Pre-Operational and Operational Tests 5

3.7 Acceptance for Beneficial Use (ABU) 6

$\begin{array}{lll}3.8 & \text { Risk Assessment } & 6\end{array}$

$\begin{array}{lll}4.0 & \text { ORGANIZATION } & 6\end{array}$

4.1 Characterization Field Engineering (CFE) 6

4.2 Characterization Engineering (CE) 6

4.3 Characterization Project Operations (CPO) 6

$\begin{array}{lll}4.4 & \text { Quality Assurance and Safety } & 7\end{array}$

4.5 Radiation Engineering (RADCON) 7

4.6 Flammable Gas Equipment Advisory Board (FGEAB) 7

$\begin{array}{lll}5.0 & \text { SCHEDULE AND COST ESTIMATE } & 7\end{array}$ 
$\begin{array}{lll}7.0 & \text { QUALITY ASSURANCE } & 8\end{array}$

8.0 SAFETY AND AUTHORIZATION BASIS

9.0 SYSTEMS ENGINEERING

$\begin{array}{ll}10.0 \text { CLOSEOUT COSTS } & 8\end{array}$

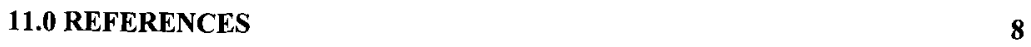

$\begin{array}{ll}\text { APPENDIX A } & 11\end{array}$ 


\subsection{INTRODUCTION}

A purged, closed circuit television system is currently used to video inside of waste tanks. The video is used to support inspection and assessment of the tank interiors, waste residues, and deployed hardware. The system is also used to facilitate deployment of new equipment. A new light source has been requested by Characterization Project Operations (CPO) for the video system. The current light used is mounted on the camera and provides 75 watts of light, which is insufficient for clear video. Other light sources currently in use on the Hanford site either can not be deployed in a 4-inch riser or do not meet the ignition source controls.

\subsection{SCOPE}

The scope of this Engineering Task Plan is to address all activities associated with the specification and procurement of a light source for use with the existing CPO video equipment. The installation design change to tank farm facilities is not within the scope of this ETP.

\subsection{DESCRIPTION}

\subsection{Physical Description}

The light system will provide adequate lighting for video inside the Hanford underground waste storage tanks. The system will be qualified for use in the highly corrosive and potentially flammable atmosphere. The light system will make use of the existing power supply or will include an upgrade to the existing power supply system if necessary. All support equipment for deployment, operation, transportation and storage will be provided.

\subsection{Engineering Tasks}

The engineering tasks contained in this work plan are the minimum necessary activities to acquire a light system that is safe to deploy in the Hanford waste tanks. The overall task is to specify and procure a system that will meet the requirements. The specification will contain all of the design, fabrication, and testing requirements and define the activities necessary to ensure the light system meets the requirements. Characterization Engineering $(\mathrm{CE})$ will complete the engineering tasks.

\subsubsection{Design Requirements}

Design criteria will be prepared and documented per sections 3.2 and 3.4 of LMHC 1998a and will be summarized in a Design Compliance Matrix per Raymond 1997b. The Authorization Basis for the light system is located in section 5.4 of LMHC 1998a.

\subsubsection{Procurement Specifications}

A specification document will be prepared per HNF 1997a for the system. 


\subsubsection{Design}

The equipment supplier will prepare the design of systems and components. The design will be documented per HNF 1997b, and HNF 1997c.

\subsubsection{Operating and Maintenance Procedures}

Operation and maintenance procedures will be prepared and/or revised as required to support the operation and maintenance of the new system.

\subsubsection{Spare Parts}

A list of recommended spare parts will be provided for long lead items that should be kept in inventory.

\subsection{Design Verification}

Design verification will be performed prior to contract award and prior to the start of fabrication. A graded approach will be used for the determination of design review requirements based upon the expected consequence of failure of the particular system. Design reviews will be conducted per HNF 1997d. Formal Design Review will be conducted for the design of components that are determined to be Safety Class (SC).

The Flammable Gas Equipment Advisory Board (FGEAB) will review the design of the system and components prior to the start of fabrication of components which will be used in locations requiring ignition source controls per LMHC $1998 \mathrm{~b}$.

\subsection{Procurement / Fabrication Tasks}

The procurement of the system will be performed as a competitive bid through standard procurement procedures. The Hanford site Procurement Services organization will perform the procurement.

Vendor proposals will go through a preliminary design review prior to award of the fabrication contract. The design will go through a final design review prior to fabrication.

\subsection{Installation Tasks}

The system will be designed to be portable. The initial installation will be completed by the organization that will operate the system, CPO. The installation ECNs to tank farm facility drawings is not within the scope of this ETP.

\subsection{Pre-Operational and Operational Tests}

Acceptance testing of off-site supplier provided systems will be performed as defined in the procurement specification. A pre-operational test will be performed on site to ensure the new systems function as required and are compatible with interacting equipment. 
Testing will be documented and conducted per HNF 1997e and HNF 1997f. A test report will be issued to document the results of acceptance and operational testing performed.

\subsection{Acceptance for Beneficial Use (ABU)}

An ABU will be developed per section 3.12 of LMHC 1998a and Raymond 1997a as part of this task. The ABU will be added as an appendix to this ETP.

\subsection{Risk Assessment}

The programmatic risk assessment will not be performed for this task. This task is requested as an operating enhancement. The scheduled completion of this task will be affected by the priorities assigned by the customer based upon project commitments. The failure to complete this task would result in the potential inability to perform some sampling events without adequate in-tank visual monitoring.

\subsection{ORGANIZATION}

\subsection{Characterization Field Engineering (CFE)}

CFE will provide Cognizant Engineer support as required for this task. CFE will prepare or revise all operating and maintenance procedures as required to support the deployment of the new system.

Cognizant Manager: JS Schofield

Cognizant Engineer: CA Esvelt

\subsection{Characterization Engineering (CE)}

CE will provide Design Authority support for this task. CE personnel will prepare all documentation associated with the development of the design requirements, procurement specifications, fabrication and testing of the new system. CE personnel will witness all testing and the Design Authority will approve the results of all testing.

Design Authority: GP Janicek

Project Manager: JL Smalley

Responsible Engineer: AJ Kostelnik

\subsection{Characterization Project Operations (CPO)}

CPO will provide review of specifications and procedures that are associated with this task. CPO should witness all off-site testing and perform all on-site testing. The logistics of performing on-site testing will be the responsibility of $\mathrm{CPO}$ with the support of CE/CFE.

Responsible Manager: TD Jarecki

Operations Representative: ML Sumsion 


\subsection{Quality Assurance and Safety}

Lockheed Martin Hanford Company (LMHC) will provide Quality Assurance and Safety support. QA and Safety will participate in the review of design, specification, and testing documents, witness testing as specified in the test procedures, and approve test results as required by HNF $1997 \mathrm{~g}$.

QA Engineer: ML McElroy

Safety Engineer: JA Ranschau

\subsection{Radiation Engineering (RADCON)}

LMHC will provide Health Physics review support. RADCON should participate in the review of design, specification, and testing documents, witness testing as specified in the test procedures, and approve test results as necessary.

\section{RADCON Engineer: DJ Foust}

\subsection{Flammable Gas Equipment Advisory Board (FGEAB)}

LMHC will provide FGEAB support. The FGEAB will participate in the review of design, specification, and testing documents as required. If applicable, the FGEAB will approve all test results as specified in the test procedures.

Responsible Manager: SH Rifaey

\subsection{SCHEDULE AND COST ESTIMATE}

The CPE Project Manager will track a detailed schedule of all tasks. A rough schedule is included in Appendix A. The schedule will support completion of a procurement specification document by January 31, 1999 and initial deployment of the light system by July 31, 1999. The scheduled completion of this task will be affected by the priorities assigned by CE and CPO based upon project commitments.

The estimated engineering cost to prepare this ETP (30-hrs), prepare a procurement specification (50-hrs), support procurement (60-hrs), support testing (80-hrs), document configuration (180-hrs) and support initial deployment (100-hrs), for a total of 500 man-hours. An additional estimate of 100 man-hours is required for Safety, QA, RADCON, and FGEAB. The estimate for CPO is 100 man-hours. The estimated material and equipment cost, assuming a purged system is built, is $\$ 75 \mathrm{~K}$.

Engineering expenses will be charged to Cost Account Charge Number (CACN) 102258 Code of Account (COA) EI00, Quality Assurance, and Safety, FGEAB, RADCON, and CPO expenses are funded separately by LMHC Characterization Engineering. 


\subsection{CONFIGURATION MANAGEMENT}

The design of the system will be documented. Standard $\mathrm{H}$-series drawings will be created to document the configuration and Essential and Support drawings will be assigned as required by HNF 1997c. A vendor information file will be established per HNF 1997b, to contain catalog cuts, performance specifications, and/or installation/operation instructions for components or systems supplied by the manufacturer. All modifications made to standard manufacturer products will be documented on $\mathrm{H}-2$ series drawings.

\subsection{QUALITY ASSURANCE}

All work associated with this task will be in compliance with LMHC 1998c. QA oversight will be provided as defined in this ETP.

\subsection{SAFETY AND AUTHORIZATION BASIS}

The light system will be used inside the underground radioactive waste tanks on the Hanford Site. The Authorization Basis for tank farms, section 5.4 of LMHC 1998a, and the applicable industry safety standards will be considered for all safety concerns associated with this task. The USQ process will be used as required per section 5.4 of LMHC 1998a.

\subsection{SYSTEMS ENGINEERING}

This activity is necessary to support the characterization of the waste in the underground waste tanks on the Hanford site. This activity supports the Tank Farms task identified in the Work Breakdown Structure (WBS) as task number 1.1.1.1.1.3.1.17, Core Sampling Systems (LMHC 1998d).

\subsection{CLOSEOUT COSTS}

An estimate will be prepared prior to the closure of the task if the task is no longer required. The amounts of all outstanding purchase agreements will be included as closeout costs.

\subsection{REFERENCES}

HNF-1998 is a newly issued engineering requirement procedure but does not become effective until March 1, 1999. At that time, many of the Project Hanford Policy and Procedure System level engineering requirements given in the HNF-PRO-XXX series of procedures will be replaced by LMHC level procedures in LMHC 1998a. A cross-reference will be developed by LMHC and utilized for the purposes of this ETP when these procedures become available. 
Boger, R. M., 1998, Lockheed Martin Hanford Corporation Task Order Number 109 rev.0, Lockheed Martin Hanford Corporation, Richland, Washington.

HNF, 1997a, HNF-PRO-241, Rev. 0, Project Hanford Policy and Procedure System Engineering Specifications Requirements, Fluor Daniel Hanford, Inc., Richland, Washington.

HNF, 1997b, HNF-PRO-444, Rev. 1, Project Hanford Policy and Procedure System Vendor Information Requirements, Fluor Daniel Hanford, Inc., Richland, Washington.

HNF, 1997c, HNF-PRO-242, Rev. 1, Project Hanford Policy and Procedure System Engineering Drawing Requirements, Fluor Daniel Hanford, Inc., Richland, Washington.

HNF, 1997d, HNF-PRO-445, Rev. 0, Project Hanford Policy and Procedure System Design

Verification Requirements, Fluor Daniel Hanford, Inc., Richland, Washington.

HNF, 1997e, HNF-PRO-446, Rev. 1, Project Hanford Policy and Procedure System Testing Practices Requirements, Fluor Daniel Hanford, Inc., Richland, Washington.

HNF, 1997f, HNF-PRO-439, Rev.0, Project Hanford Policy and Procedure System Supporting Document Requirements, Fluor Daniel Hanford, Inc., Richland, Washington.

HNF, 1997g, HNF-PRO-233, Rev 0, Project Hanford Policy and Procedure System Review and Approval of Documents, Fluor Daniel Hanford, Inc., Richland, Washington.

HNF, 1998, HNF-PRO-1819, Rev, 0, Project Hanford Policy and Procedure System PHMC Engineering Requirements, Fluor Daniel Hanford, Inc., Richland, Washington.

LMHC, 1998a, HNF-IP-0842, Tank Waste Remediation System Administration Manual, Volume IV Engineering, latest revision, Lockheed Martin Hanford Corporation, Richland, Washington

LMHC, 1998b, Tank Waste Remediation System Basis for Interim Operation, HNF-SD-WMBIO-001, latest revision, Lockheed Martin Hanford Corporation, Richland, Washington

LMHC, 1998c, Tank Waste Remediation System Characterization Project Quality Policies, HNF-SD-WM-QAPP-025, latest revision, Lockheed Martin Hanford Corporation, Richland, Washington.

LMHC, 1998d, HNF-SP-1230, Rev.1, Tank Waste Remediation System Waste Characterization Fiscal Year 1999 Multi-Year Work Plan WBS 1.1, Lockheed Martin Hanford Corporation, Richland, Washington.

Raymond, R. E., 1997a, Acceptance for Beneficial Use (ABU), Characterization Project Desk Instruction DI-CP-004-00, Revision 1, Westinghouse Hanford Company, Richland, Washington. 
Raymond, R. E., 1997b, Design Compliance Matrix, Characterization Project, Project Instruction PI-CP-008-00, Revision 0, Lockheed Martin Hanford Corporation, Richland, Washington. 
HNF-3640

Rev.0

Appendix A 


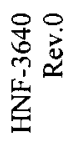

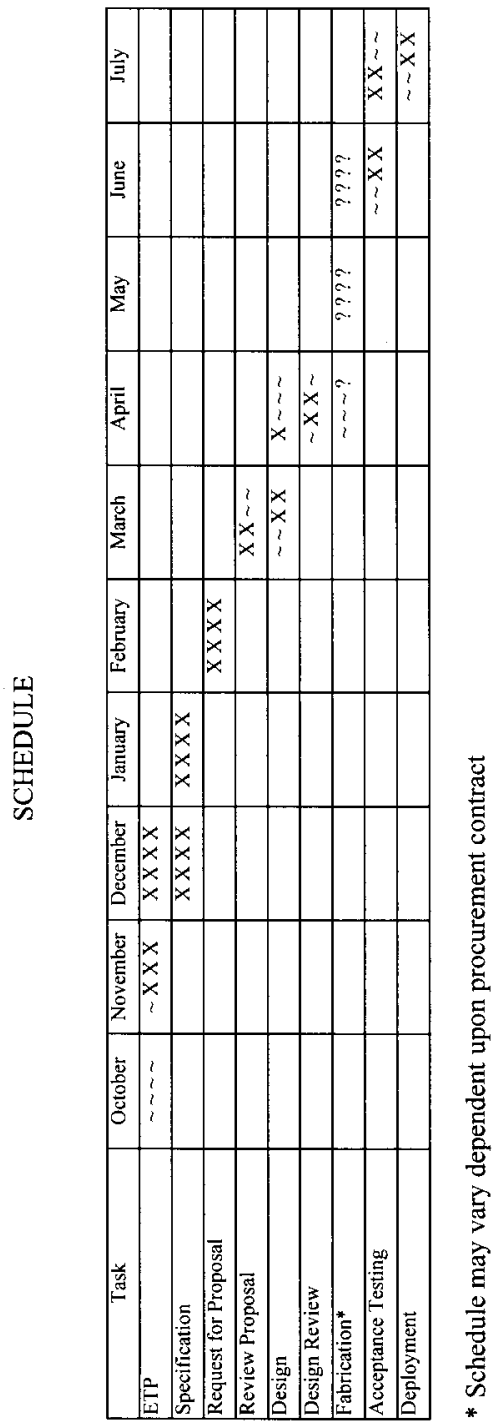

